\title{
Yield and nutritional status of the conilon coffee tree in organic fertilizer systems ${ }^{1}$
}

\author{
Produtividade e estado nutricional do cafeeiro conilon em sistemas de adubação \\ orgânica
}

\author{
Victor Maurício da Silva ${ }^{2 *}$, Alex Fabian Rabelo Teixeira ${ }^{3}$,Edvaldo Fialho dos Reis ${ }^{4}$ e Eduardo de Sá Mendonça ${ }^{5}$
}

\begin{abstract}
The conilon coffee tree presents high yield potential, the replacement of soil nutrients usually being by the use of mineral fertilizers. To reduce these fertilizers, the use of organic waste may be an alternative. The objective of this study was to evaluate the effect of organic fertilizer systems on the nutritional status and yield of the conilon coffee tree. On a farm, located in the town of Linhares, Espirito Santo, during the agricultural year of 2009/2010, a trial was set up using a completely randomized block design with a factorial distribution of $2 \times 2 \times 5$ and three replications, the factors being: organic compost (compost 1 and compost 2 ); legumes (the presence and absence of jack beans, sown between the rows of coffee trees); and the proportions of each compost $(0 ; 25 ; 50 ; 75$ and $100 \%)$ as a substitute for the recommended mineral fertilizer. The increase in the proportion of compost 2 was reflected as increases in the $\mathrm{P}$ content of the leaves due to the higher concentration of this nutrient in the compost. The increase in compost input increased the $\mathrm{S}$ content of the leaves as a response to the increase in soil $\mathrm{pH}$. Maximum values of 61 and 66 sacks ha- 1 were obtained with substitutions (mineral source by organic) in the proportion of 40 and $37 \%$ for compost 1 and compost 2 respectively. The use of organic-waste composts is an alternative as a partial replacement of mineral fertilizers in the conilon coffee tree, resulting in increases in yield.
\end{abstract}

Key words: Nutrient uptake. Compost. Legumes. Family farmer.

RESUMO - O cafeeiro conilon apresenta alto potencial produtivo e a reposição dos nutrientes no solo é geralmente por meio de adubos minerais. Para reduzir esses adubos, o uso de resíduos orgânicos na propriedade agrícola pode ser uma alternativa. O objetivo do trabalho foi avaliar o efeito de sistemas de adubação orgânica sobre o estado nutricional e a produtividade do cafeeiro conilon. Em lavoura localizada no município de Linhares-ES, foi montado, no ano agrícola 2009/2010, experimento em blocos casualizados com distribuição fatorial de $2 \times 2 \times 5$, com três repetições, sendo os fatores: composto orgânico (composto 1 e composto 2); leguminosa (presença e ausência do feijão-de-porco semeado nas entrelinhas dos cafeeiros); e, proporções de cada composto $(0 ; 25 ; 50 ; 75$ e 100\%) em substituição à adubação mineral recomendada. O aumento das proporções do composto 2 refletiu em incrementos nos teores foliares de $\mathrm{P}$ devido à maior concentração desse nutriente nesse composto. $\mathrm{O}$ aumento do aporte de compostos incrementou os teores foliares de $\mathrm{S}$ em resposta ao acréscimo do $\mathrm{pH}$ do solo. Valores máximos de 61 e 66 sacas ha-1 foram obtidos com proporções de substituição (da fonte mineral por orgânica) de 40 e $37 \%$ para o composto 1 e composto 2 , respectivamente. A utilização de compostos de resíduos orgânicos é uma alternativa para substituir parcialmente a adubação mineral no cafeeiro conilon com incrementos na produtividade.

Palavras-chave: Absorção de nutrientes. Composto. Leguminosa. Agricultor familiar.

\footnotetext{
*Autor para correspondência

${ }^{1}$ Recebido para publicação em 30/08/2012; aprovado em 30/06/2013

Parte da Dissertação de Mestrado do primeiro autor apresentada no Programa de Pós-Graduação em Produção Vegetal da Universidade Federal do Espírito Santo; pesquisa financiada pela SAF/MDA, SECIS/MCT, por intermédio do CNPq

${ }^{2}$ Programa de Pós-Graduação em Produção Vegetal, CCA/Universidade Federal do Espírito Santo/UFES, Alegre-ES, Brasil, 29.500-000, victor-mauricio@bol.com.br

${ }^{3}$ Instituto Capixaba de Pesquisa, Assistência Técnica e Extensão Rural/INCAPER, Linhares-ES, Brasil, 29.052-010, afabian @incaper.es.gov.br

${ }^{4}$ Departamento de Engenharia Rural, Universidade Federal do Espírito Santo/CCA/UFES, Alegre-ES, Brasil, 29.500-000, edreis@cca.ufes.br

${ }^{5}$ Departamento de Produção Vegetal, Universidade Federal do Espírito Santo/CCA/UFES, Alegre-ES, Brasil, 29.500-000, eduardo.mendonca@ufes.br
} 


\section{INTRODUCTION}

Because of the high demand of the conilon coffee tree (Coffea canephora Pierre ex Froehner), the replacement of nutrients to the soil is usually done by means of mineral fertilizers of high solubility (PREZOTTI et al. 2007). However, due to international dependence on mineral fertilizers and their high cost, supplying the correct amounts can be an obstacle for rural farmers (SERRANO; SILVA; FORMENTINI, 2011). In the state of Espírito Santo, Brazil, the problem is compounded because the greater part of coffee production is concentrated in small family-based rural farms, which by their nature are badly financed.

An alternative in order to reduce mineral fertilizer is the use of organic sources on the farm. Theodoro; Mendes; Guimarães (2009), evaluated the effect of organic fertilizers on the yield of Arabica coffee and found that the use of castor meal resulted in higher productivity compared to cattle manure and poultry litter, with an average of 47 bags ha $^{-1}$. Moreover, management of organic fertilization can influence the dynamics of the nutritional status of the coffee plant. Serrano, Silva and Formentini (2011), studying foliar levels in conilon coffee when growing, found that an increase in the levels of organic compost produced a linear decrease in leaf $\mathrm{Ca}$ levels, and an increase in those of $\mathrm{K}$.

Studying the nutritional status of the adult conilon coffee plant, Bragança, Prezotti and Lani (2007) determined appropriate limits for leaf macronutrient concentrations which can be used to support discussions related to the effect of fertilization managements, these being: 29 to $32 \mathrm{~g} \mathrm{~kg}^{-1} \mathrm{~N} ; 1.2$ to $1.6 \mathrm{~g} \mathrm{~kg}^{-1} \mathrm{P} ; 20$ to $25 \mathrm{~g} \mathrm{~kg}^{-1} \mathrm{~K} ; 10$ to $15 \mathrm{~g} \mathrm{~kg}^{-1} \mathrm{Ca} ; 3.5$ to $4 \mathrm{~g} \mathrm{~kg}^{-1}$ of $\mathrm{Mg}$; and 2.0 to $2.5 \mathrm{~g} \mathrm{~kg}^{-1} \mathrm{~S}$. Similarly, Partelli et al. (2006a) obtained the following averages for foliar levels in crops of adult conilon under both organic and conventional systems respectively: 27.6 and $26.4 \mathrm{~g} \mathrm{~kg}^{-1} \mathrm{~N}$; 1.6 and $1.4 \mathrm{~g} \mathrm{~kg}^{-1}$ of $\mathrm{P} ; 16.7$ and $18.5 \mathrm{~g} \mathrm{~kg}^{-1} \mathrm{~K} ; 13.5$ and $11.6 \mathrm{~g} \mathrm{~kg}^{-1} \mathrm{Ca} ; 3.5$ to $3.6 \mathrm{~g} \mathrm{~kg}^{-1} \mathrm{Mg}$; and 2.1 to $1.8 \mathrm{~g} \mathrm{~kg}^{-1} \mathrm{~S}$.

Unlike that recorded for Coffea canephora, studies on the effect of organic fertilizer in Coffea arabica are found frequently in the literature (ARAÚJO et al., 2007; ARAÚJO et al., 2008; RANGEL et al., 2008; RICCI et al., 2005; THEODORO et al., 2003). Therefore, studies carried out on family farms are crucial to the development of strategies that incorporate organic residues into fertilizer, with a view to reducing the dependence of the conilon coffee plant on mineral fertilizers.

The objective of this work was to evaluate the effect of different organic fertilization managements on the nutritional status and productivity of the conilon coffee plant in the state of Espírito Santo, Brazil.

\section{MATERIAL AND METHODS}

The study was carried out on an irrigated crop of conilon coffee, on a family-based property located in the Córrego do Farias district of Linhares, Espitito Santo, Brazil (19 $15^{\prime} 67^{\prime}, \mathrm{S}$ and $40^{\circ} 01^{\prime} 93^{\prime}$ ' $\mathrm{W}$ and a height of $17 \mathrm{~m}$ ), from November, 2009 to June, 2011. According to the Köppen classification, the regional climate is of type Awi, characterized as hot and humid, with a rainy season in the summer and dry in the winter, having an average annual rainfall of $1,200 \mathrm{~mm}$ and an average temperature of $25^{\circ} \mathrm{C}$. The selected crop was of about 0.75 ha in size and four years old, grown at a spacing of $3.0 \times 1.2 \mathrm{~m}$ and made up of 2 clones, $12 \mathrm{~V}$ - a component of the variety "Victory INCAPER 8142", and G 35 from the Verdebras company.

The soil of the area is a dystrophic RedYellow Argisol, formed over sediments of the Barriers Formation (EMPRESA BRASILEIRA DE PESQUISA AGROPECUÁRIA, 2006). Before the study, a particle-size and chemical analysis of the area at a depth of 0 to $20 \mathrm{~cm}$ showed the following characteristics: sandy- loam in texture; $\mathrm{pH}\left(\mathrm{H}_{2} \mathrm{O}\right) 5.6 ; 1.9 \mathrm{dag} \mathrm{kg}^{-1}$ organic matter; 7 $\mathrm{mg} \mathrm{dm}{ }^{-3} \mathrm{P} ; 44 \mathrm{mg} \mathrm{dm}^{-3} \mathrm{~K} ; 1.3 \mathrm{cmol}_{\mathrm{c}} \mathrm{dm}^{-3} \mathrm{Ca} ; \mathrm{cmol}_{\mathrm{c}} 0.3$ $\mathrm{dm}^{-3} \mathrm{Mg} ; 0.1 \mathrm{cmol}_{\mathrm{c}} \mathrm{dm}^{-3} \mathrm{Al} ; 2.1 \mathrm{cmol}_{\mathrm{c}} \mathrm{dm}^{-3} \mathrm{H}+\mathrm{Al} ; 1.7$ $\mathrm{cmol}_{\mathrm{c}} \mathrm{dm}^{-3}$ sum of bases (SB), $44.9 \%$ base saturation (V); $71 \mathrm{mg} \mathrm{dm}^{-3} \mathrm{Fe} ; 1.2 \mathrm{mg} \mathrm{dm}^{-3} \mathrm{Zn} ; 0.3 \mathrm{mg} \mathrm{dm}^{-3} \mathrm{Cu} ; 29 \mathrm{mg}$ $\mathrm{dm}^{-3} \mathrm{Mn}$; and $0.16 \mathrm{mg} \mathrm{dm}^{-3} \mathrm{~B}$ (EMPRESA BRASILEIRA DE PESQUISA AGROPECUÁRIA, 1997).

Before implementation of the experiment, liming was carried out employing the base-saturation method, in order to bring it up to $70 \%$. Foliar fertilization with micronutrients was performed in three applications: the first on 09/2010, the second on 10/2010 and the third on 11/2010 (PREZOTTI et al., 2007). For this, the commercial product Ubyfol - MS 77 (4.5\% B, 0.1\% Co, $2 \%$ $\mathrm{Cu}, 1 \% \mathrm{Fe}, 1 \% \mathrm{Mn}, 0.1 \% \mathrm{Mo}$ and $13 \% \mathrm{Zn}$ ) was used.

The experiment was set up in a $2 \times 2 \times 5$ factorial arrangement consisting of: organic compost (composts $\mathrm{C} 1$ and $\mathrm{C} 2$ ); legumes (presence and absence of); and proportions of each compost in five different amounts $(0 ; 25 ; 50 ; 75$ and $100 \%)$. A randomized-block design with three replications was used. Each replication was made up of a lot of 30 conilon coffee plants, with the 12 central plants being considered.

The composts used were: Compost 1 (C1), prepared by mixing elephant grass (Pennisetum purpureum Schumach) and coffee straw in the proportion of 1:1 (v: v), and Compost $2(\mathrm{C} 2)$, prepared by mixing elephant grass, coffee straw and poultry litter in the proportion of $2: 1: 1(\mathrm{v}: \mathrm{v}: \mathrm{v})$. Before building the windrows, grass at 180 days of regrowth, was removed from a grassy area and shredded to a size of $2 \mathrm{~cm}$. 
Setting up windrows of the compost was done on the same day as cutting the grass. C1 was set up by alternately stacking $50 \mathrm{~cm}$ high layers of vegetable residue. For $\mathrm{C} 2$, the layers were arranged with heights of $50 \mathrm{~cm}$ for the grass, $25 \mathrm{~cm}$ for the coffee straw and $25 \mathrm{~cm}$ for the poultry litter. Only one manual turning of the compost was carried out, 45 days after setting up the windrows. To guarantee uniform moistening, it was decided to irrigate once a week, always ensuring that the windrows received the same volume of water. On rainy days, plastic tarpaulins were used as cover.

After 120 days composting, using observed physical characteristics (mostly colour, temperature and particle size), the composts were found to be suitable for use. Samples were then chemically characterised at the Laboratory for Soil and Plant Analysis of INCAPER/ CRDR-CS (Table 1).

The legume used was the jack bean (Canavalia ensiformis), sown manually between rows in the 1st and 2nd agricultural years in November, 2009 and January, 2011 respectively. The spacing used when planting was of $1 \mathrm{~m}$ from the stem of the coffee plant and $50 \mathrm{~cm}$ between rows (giving three rows of legumes). Eight seeds were sown per linear meter of each rut. The plants were cut down at the flowering stage, 90 days after planting. After cutting, the hay was left whole and used as cover.

For the first and second crop years (2009/2010 and 2010/2011 respectively), treatment with added nutrients from mineral sources only (control or $0 \%$ organic matter) consisted in the application of $380 \mathrm{~kg} \mathrm{ha}^{-}$ ${ }^{1} \mathrm{yr}^{-1}$ of $\mathrm{N}$ in the form of ammonium sulphate for an expected productivity of 51-70 bags ha-1 (PREZOTTI et al., 2007). For fertilization with phosphorus and potassium in the first year, $60 \mathrm{~kg} \mathrm{ha}^{-1} \mathrm{yr}^{-1}$ of $\mathrm{P}_{2} \mathrm{O}_{5}$ and
$350 \mathrm{~kg} \mathrm{ha}^{-1} \mathrm{yr}^{-1}$ of $\mathrm{K}_{2} 0$ were used, in the form of single superphosphate and potassium chloride respectively (PREZOTTI et al., 2007). In the second crop year, due to the residual effect of the fertilizer from the first year, phosphorus and potassium fertilization was carried out taking into consideration both that in the soil and the expected productivity (PREZOTTI et al., 2007).

The treatments with organic sources were determined from the $\mathrm{N}$ content of the organic composts, and from recommendations for mineral fertilization (PREZOTTI et al., 2007). For the first crop year, for the treatment with an exclusively organic source (100\% organic compost), 25.33 $\mathrm{Mg} \mathrm{ha}^{-1} \mathrm{yr}^{-1}$ of $\mathrm{C} 1$ and $12.50 \mathrm{Mg} \mathrm{ha}^{-1} \mathrm{yr}^{-1}$ of $\mathrm{C} 2$ (moist) were applied. For the second crop year, treatment consisted in the application of $42.44 \mathrm{Mg} \mathrm{ha}^{-1} \mathrm{yr}^{-1}$ of $\mathrm{C} 1$ and $27.40 \mathrm{Mg} \mathrm{ha}^{-1} \mathrm{yr}^{-1}$ of C2 (moist). In the first year the humidity of the composts was not taken into account when correcting the fertilization calculations. In the second year the $51 \%$ humidity of $\mathrm{C} 1$ and $39 \%$ humidity of $\mathrm{C} 2$ were taken into consideration.

Fertilizer was combined with the above-mentioned mineral sources in the proportions of $25 ; 50$ and $75 \%$ of the amounts of organic compost. Therefore for $25 ; 50$ and $75 \%$ organic compost, $75 ; 50$ and $25 \%$ from mineral sources were used respectively. The fertilizers were applied to the canopy projection and around the entire plant.

In first crop year, fertilization was divided into four stages: $1^{\text {st }}$ stage (20\% of the fertilizer) in November, 2009; $2^{\text {nd }}$ stage $\left(20 \%\right.$ of the fertilizer) in December, 2009; $3^{\text {rd }}$ stage $\left(20 \%\right.$ of the fertilizer) in March, 2010; and $4^{\text {th }}$ stage (40\% of the fertilizer) in 2010/04. In the second year, fertilization was split into two stages: $1^{\text {st }}$ stage (50\% of the fertilizer) in January, 2011; and $2^{\text {nd }}$ stage (50\% of the fertilizer) in April, 2011.

Table 1 - Chemical characterisation (dried basis) of composts 1 (C1) and 2 (C2) from the 1st and 2nd crop years, at 120 days after setting up the windrows

\begin{tabular}{|c|c|c|c|c|c|c|c|c|c|c|}
\hline \multirow{2}{*}{${ }^{1}$ Type } & ${ }^{2}$ Humid. & ${ }^{3} \mathrm{OM}$ & \multirow{2}{*}{$\mathrm{C} / \mathrm{N}$} & \multirow{2}{*}{${ }^{4} \mathrm{pH}$} & $\mathrm{N}$ & $\mathrm{P}$ & $\mathrm{K}$ & $\mathrm{Ca}$ & $\mathrm{Mg}$ & S \\
\hline & $\%$ & $\%$ & & & \multicolumn{6}{|c|}{ 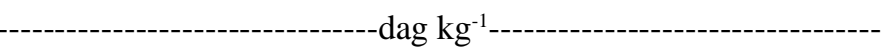 } \\
\hline \multicolumn{11}{|c|}{ 1st crop year $(2009 / 2010)$} \\
\hline $\mathrm{C} 1$ & 64.0 & 68.6 & 23 & 7.6 & 1.5 & 0.3 & 1.7 & 0.6 & 0.2 & 0.1 \\
\hline $\mathrm{C} 2$ & 59.5 & 62.8 & 10 & 7.1 & 3.0 & 3.5 & 3.1 & 3.6 & 0.7 & 0.4 \\
\hline \multicolumn{11}{|c|}{ 2nd crop year $(2010 / 2011)$} \\
\hline $\mathrm{C} 1$ & 50.9 & 49.4 & 14 & 7.2 & 1.8 & 2.2 & 2.1 & 1.0 & 0.1 & 0.2 \\
\hline $\mathrm{C} 2$ & 39.4 & 51.6 & 12 & 6.8 & 2.3 & 3.6 & 2.9 & 4.2 & 0.5 & 0.3 \\
\hline
\end{tabular}

${ }^{1}$ Type: $\mathrm{C} 1$ (compost 1), prepared by mixing elephant grass (Pennisetum purpureum) and cofee straw in the proportion of 1:1 (v:v); C2 (compost 2), prepared by mixing elephant grass, coffee straw e poultry litter in the proportion of 2:1:1 (v:v:v); ${ }^{2}$ Humid.: humidity of the organic composts; ${ }^{3} \mathrm{OM}$.: organic matter; ${ }^{4} \mathrm{pH}$ em $\mathrm{CaCl}_{2}$ 
In order to characterize the nutritional state of the plants, in September of 2010 leaves were collected from the middle third of the plants, at the third leaf pair counting from the apex of the horizontal branches on the four cardinal points of the plants and lots. Fifty leaves were collected from each lot and the material dried in a forced ventilation oven at $70{ }^{\circ} \mathrm{C}$ until reaching constant weight, and ground in a Wiley mill. The samples were then sent to the Laboratory for Soil and Leaf Analysis of INCAPER/ CRDR-CS for quantification of the leaf macronutrient content, as per Malavolta, Vitti and Oliveira (1989).

In order to have a better interpretation and discussion of the leaf nutrient content, in August of 2010 the chemical attributes of the soil at a depth of 0-20 $\mathrm{cm}$, were characterised. In each lot, with the help of a probe (SONDATERRA (B), single samples were taken from under the canopy of the 12 experimental plants in order to make up one composite sample. The samples were sent to the Laboratory for Soil Analysis of INCAPER/CRDR-NE for the quantification of $\mathrm{pH}$ and macronutrient values (EMPRESA BRASILEIRA DE PESQUISA AGROPECUÁRIA, 1997). The characterisation data are shown in Table 2.

Harvesting the fruits of the coffee plants was carried out in June, 2011. In order to determine productivity the total volume (in litres) produced per lot was quantified. A representative sample of 2 litres was taken from the total volume, and dried on a raised terrace to about $14 \%$ humidity. The samples were then peeled in an electric peeler and the humidity measured to reach $13 \%$ by mathematical equation. They were then weighed with precision scales and converted into values for productivity, as sacks produced per hectare (sacks ha-1).

The data were subjected to preliminary tests to verify the normality and homogeneity of variance by means of the Lilliefors and Bartlett tests respectively. They were subsequently subjected to variance analysis $(p \leq 0.10)$ using the SISVAR software. When significant, the Tukey test $(p \leq 0.10)$ was used for the

Table 2 - Chemical characterisation of the soil at a depth of 0-20 cm, for all fertilization treatments of the conilon coffee plant

\begin{tabular}{|c|c|c|c|c|c|c|}
\hline \multirow{2}{*}{${ }^{1}$ Treatments } & \multirow{2}{*}{${ }^{2} \mathrm{pH}$} & $\mathrm{Al}$ & $\mathrm{Ca}$ & $\mathrm{Mg}$ & $\mathrm{P}$ & $\mathrm{K}$ \\
\hline & & \multicolumn{3}{|c|}{ - } & \multicolumn{2}{|c|}{ - } \\
\hline MFJ & 4.80 & 0.17 & 1.05 & 0.32 & 38.30 & 129.33 \\
\hline MF & 4.87 & 0.25 & 1.26 & 0.34 & 34.80 & 126.67 \\
\hline $\mathrm{F} 25 \mathrm{C} 1 \mathrm{~J}$ & 5.17 & 0.08 & 1.48 & 0.40 & 29.77 & 198.00 \\
\hline $\mathrm{F} 25 \mathrm{C} 1$ & 5.33 & 0.13 & 1.50 & 0.54 & 40.67 & 148.67 \\
\hline F50C1J & 4.80 & 0.14 & 1.19 & 0.44 & 23.47 & 187.33 \\
\hline F50C1 & 5.00 & 0.13 & 1.29 & 0.46 & 26.77 & 174.33 \\
\hline F75C1J & 5.23 & 0.07 & 1.84 & 0.59 & 26.97 & 261.00 \\
\hline F75C1 & 5.23 & 0.04 & 1.31 & 0.54 & 15.00 & 156.00 \\
\hline $\mathrm{F} 100 \mathrm{C} 1 \mathrm{~J}$ & 6.53 & 0.00 & 2.11 & 0.82 & 16.87 & 530.00 \\
\hline F100C1 & 6.50 & 0.00 & 1.60 & 0.65 & 11.77 & 346.33 \\
\hline $\mathrm{F} 25 \mathrm{C} 2 \mathrm{~J}$ & 4.70 & 0.18 & 1.01 & 0.34 & 54.47 & 197.00 \\
\hline $\mathrm{F} 25 \mathrm{C} 2$ & 4.93 & 0.12 & 1.18 & 0.40 & 39.00 & 210.33 \\
\hline F50C2J & 4.70 & 0.19 & 1.16 & 0.41 & 50.30 & 156.33 \\
\hline F50C2 & 5.00 & 0.06 & 1.41 & 0.46 & 41.87 & 118.67 \\
\hline F75C2J & 4.97 & 0.12 & 1.59 & 0.57 & 49.37 & 226.33 \\
\hline F75C2 & 5.17 & 0.06 & 1.34 & 0.53 & 49.00 & 150.67 \\
\hline $\mathrm{F} 100 \mathrm{C} 2 \mathrm{~J}$ & 6.43 & 0.00 & 1.64 & 0.72 & 61.00 & 199.67 \\
\hline F100C2 & 6.27 & 0.00 & 1.72 & 0.64 & 59.20 & 258.33 \\
\hline
\end{tabular}

${ }^{1}$ Meanings of the abreviations of the treatments: $\mathrm{MFJ}=$ mineral fertilizer with jack bean; MF $=$ mineral fertilizer; F $25 \mathrm{C} 1 \mathrm{~J}=\mathrm{Fertilizer}$ with $25 \%$ of compost 1 e jack bean; F25C1 = Fertilizer with $25 \%$ of compost $1 ;$ F50C1J = Fertilizer with $50 \%$ of compost 1 e jack bean; F50C1 = Fertilizer with $50 \%$ of compost 1 ; F75C1J = Fertilizer with $75 \%$ of compost 1 e jack bean; F75C1 = Fertilizer with 75\% of compost 1 ; F100C1J = Fertilizer with $100 \%$ of compost 1 e jack bean; F100C1 = Fertilizer with $100 \%$ of compost 1 ; F25C2J = Fertilizer with $25 \%$ of compost 2 e jack bean; F25C2 = Fertilizer with $25 \%$ of compost 2; F50C2J = Fertilizer with 50\% of compost 2 e jack bean; F50C2 = Fertilizer with 50\% of compost 2 ; F75C2J $=$ Fertilizer with $75 \%$ of compost 2 e jack bean; F75C2 = Fertilizer with $75 \%$ of compost $2 ;$ F100C $2 \mathrm{~J}=$ Fertilizer with $100 \%$ of compost 2 e jack bean; F100C $2=$ Fertilizer with $100 \%$ of compost $2 .{ }^{2} \mathrm{pH}$ in water (ratio $1: 2.5$ ) 
qualitative factors, and regression analysis $(\mathrm{p} \leq 0.10)$ for the quantitative factors. The models were chosen based on the significance of regression coefficients, using Student's t-test at a level of $10 \%$.

\section{RESULTS AND DISCUSSION}

Table 3 shows the results of the variance analysis for those variables analysed. It was found that productivity (bags produced per hectare) adjusted to the quadratic model concomitant with the increase in proportion of the two organic composts (Figure 1). From this behaviour it can be inferred that partial substitution of the mineral fertilizer by the organic favoured productivity. Only the highest proportion of compost caused a reduction in productivity. It is known that the positive effects of organic materials added to the soil occur over time (MELO; SILVA; DIAS, 2008). Splitting fertilization and not releasing nutrients in the period of greatest need of the coffee plants (the final stage of grain formation and start of fruit maturation) may explain some of the lowest yields for the $100 \%$ substitution ratio. The heavy infestation of scale insects in those treatments with a greater addition of compost is another factor that may have led to reduced productivity (field observation).

According to the responses observed in Figure 1, it was possible to estimate the proportion of compost and mineral fertilizer suitable for obtaining maximum values for productivity. Maximum values of 61 and 66 bags ha- ${ }^{-1}$ were obtained with substitution ratios (of the mineral source by the organic) of $40 \%$ and $37 \%$ for $\mathrm{C} 1$ and $\mathrm{C} 2$ respectively. These productivity values were close to the average (obtained by evaluating eight consecutive harvests) of 72 bags $^{-1}$ for the conilon "Victory INCAPER" 8142 variety (FERRÃO et al., 2007), and more than 51 bags ha-1 obtained in the fourth harvest of plants propagated by cuttings and under organic fertilization (PARTELLI et al., 2006b).

Not correcting the humidity of the composts in fertilization calculations in the first crop year, resulted in a lower input of $\mathrm{N}$ with the increase in the proportions of the composts. Thus, carrying out organic fertilization based on the recommendations of $\mathrm{N}$ for mineral fertilization should be revised, since higher yields were obtained with reduced amounts of $\mathrm{N}$ compared to the control (mineral fertilizer) which received the recommended amount according to Prezotti et al. (2007). Organic molecules originating from decomposed and humified waste (humic substances, for example) may have physiological effects on the plant, allowing development independently of the supply of nutrients (NARDI et al., 2002).

For productivity and leaf macronutrient content, there were generally no pronounced effects of the legume $(p>0.10)$, probably due to its high rate of decomposition associated with the application of the straw waste as soil cover, as well as the low concentration of nutrients in the plant (Table 3).

Regarding leaf N, K, P and S content, when compared to the leaf content of adult plants (BRAGANÇA; PREZZOTTI; LANI, 2007; PARTELLI et al., 2006a), the overall averages were within or above the sufficiency range recommended by these authors.

For leaf $\mathrm{N}$ and $\mathrm{K}$ content, there was no difference ( $p>0.10)$ among the treatments, whereas foliar P levels

Table 3 - Mean squares and coefficients of variation (CV) for productivity values and leaf macronutrient levels as a function of the amounts or proportions $(0 ; 25 ; 50 ; 75$ and $100 \%)$ of organic compost, both in the presence and absence of legumes (jack bean)

\begin{tabular}{|c|c|c|c|c|c|c|c|c|}
\hline \multirow{2}{*}{ Sources of variation } & \multirow{2}{*}{ GL } & \multicolumn{7}{|c|}{ Mean Squares } \\
\hline & & 'Prod. & $\mathrm{N}$ & $\mathrm{P}$ & $\mathrm{K}$ & $\mathrm{Ca}$ & $\mathrm{Mg}$ & $S$ \\
\hline Block & 2 & $96.93 *$ & $11.32^{\mathrm{ns}}$ & $0.20 * *$ & $34.54 *$ & $3.95 * *$ & $0.08^{\mathrm{ns}}$ & $0.28 * *$ \\
\hline Compost & 1 & $47.44^{\mathrm{ns}}$ & $0.02^{\mathrm{ns}}$ & $0.11 \mathrm{~ns}$ & $19.72^{\text {ns }}$ & $0.50^{\mathrm{ns}}$ & $0.00^{\mathrm{ns}}$ & $0.10^{\mathrm{ns}}$ \\
\hline Legume & 1 & $70.35^{\mathrm{ns}}$ & $2.82^{\mathrm{ns}}$ & $0.22 *$ & $17.28^{\mathrm{ns}}$ & $5.10^{* *}$ & $0.34 * *$ & $0.03^{\mathrm{ns}}$ \\
\hline Dosage & 4 & $4294.67 * * *$ & $13.31^{\mathrm{ns}}$ & $0.57 * * *$ & $24.73^{*}$ & $4.32 * * *$ & $0.08^{\mathrm{ns}}$ & $0.54 * *$ \\
\hline Compost/legume & 1 & $459.65^{* * *}$ & $46.82 * *$ & $0.09^{\text {ns }}$ & $26.14^{\mathrm{ns}}$ & $0.00^{\mathrm{ns}}$ & $0.04^{\mathrm{ns}}$ & $0.00^{\mathrm{ns}}$ \\
\hline Compost/dosage & 4 & $46.89^{\text {ns }}$ & $0.56^{\mathrm{ns}}$ & $0.11^{\mathrm{ns}}$ & $19.90^{\mathrm{ns}}$ & $0.26^{\mathrm{ns}}$ & $0.11^{\mathrm{ns}}$ & $0.06^{\mathrm{ns}}$ \\
\hline Legume/dosage & 4 & $52.16^{\mathrm{ns}}$ & $7.02^{\mathrm{ns}}$ & $0.08^{\mathrm{ns}}$ & $6.00^{\text {ns }}$ & $1.70^{\mathrm{ns}}$ & $0.15^{*}$ & $0.02^{\mathrm{ns}}$ \\
\hline Compost/legume/dosage & 4 & $173.75^{* * *}$ & $4.27^{\mathrm{ns}}$ & $0.04^{\mathrm{ns}}$ & $9.25^{\mathrm{ns}}$ & $1.06^{\mathrm{ns}}$ & $0.04^{\mathrm{ns}}$ & $0.01^{\mathrm{ns}}$ \\
\hline $\mathrm{CV} \%$ & & 15.06 & 7.82 & 12.43 & 11.68 & 10.53 & 11.13 & 10.66 \\
\hline
\end{tabular}

${ }^{1}$ Prod.: productivity; ***; **; *: significant at $1 ; 5$ and $10 \%$, respectively; and ${ }^{\text {ns }}$ not significant by the F-test 
Figure 1 - Mean productivity values (sacks ha ${ }^{-1}$ ) as a function of the proportions (\%) of compost 1 (a) and compost 2 (b) in the presence and absence of legumes (jack bean). DMS (Tukey at 10\%) for studying the factor legume at the proportions of the composts: 8.5023 . Vertical bars: standard error. ***,**,*: Significant at 1, 5 and $10 \%$ respectively, by Student's t-test

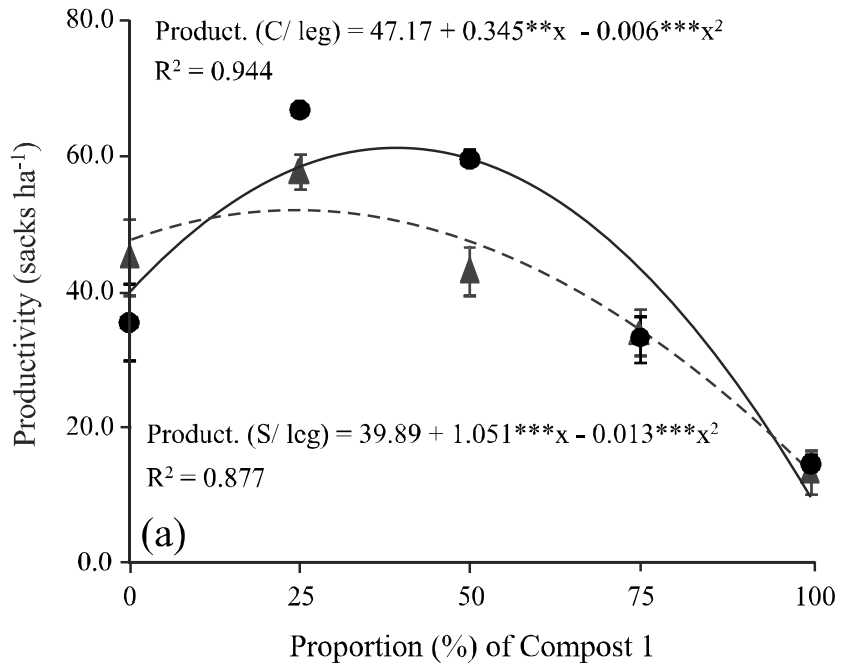

With legumes

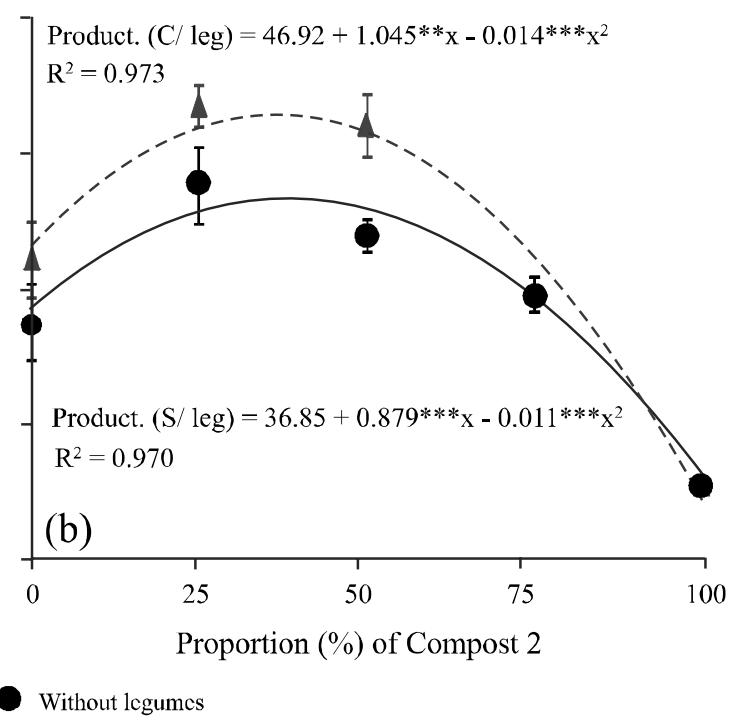

to the inorganic colloids in the soil, making the $\mathrm{P}$ more readily available to the plants (ANDRADE et al., 2003; GUAÇONI; MENDONÇA, 2003; PARTELLI et al., 2006a; RHEINHEIMER; ANGHINONI; CONTE, 2003).

As for the foliar S levels, there was a fit to the quadratic model with the increase in proportions of $\mathrm{C} 1$ in the presence of legumes, and linear increases with the increase in proportions of C2 (Figure 3). Input of the composts tended to reduce soil acidity (Table 2) with

Figure 2 - Average leaf phosphorus (P) content as a function of the proportions (\%) of compost 1 (a) and compost 2 (b) in the presence and absence of legumes (jack bean). DMS (Tukey at 10\%) for studying the factor legume at the proportions of the composts: 0.337 . Vertical bars: standard error. ***,**,*: Significant at $1 ; 5$ and $10 \%$, respectively by Student's t-test

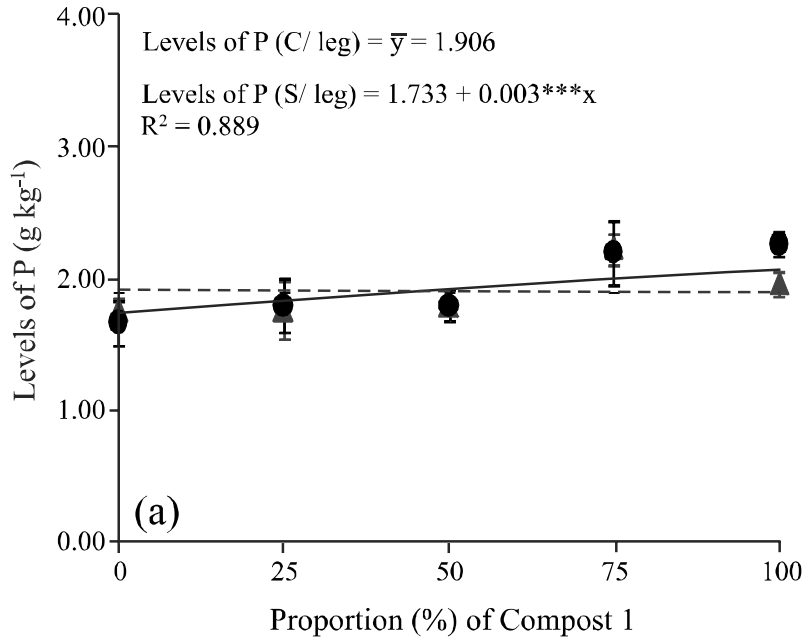

$\triangle$ With legumes

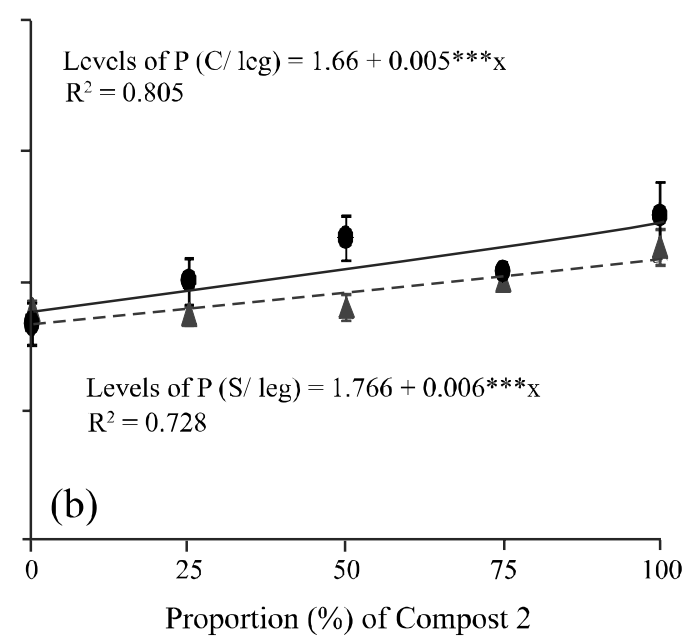

Without legumes 
Figure 3 - Average leaf content of sulphur (S), calcium $(\mathrm{Ca})$ and magnesium $(\mathrm{Mg})$ as a function of the proportion (\%) of compost 1 (a) and compost 2 (b) in the presence and absence of legumes (jack bean). DMS (Tukey at 10\%) for studying the factor legume at the proportions of the composts: $\mathrm{S}-0.3719 ; \mathrm{Ca}-1.3353$; and $\mathrm{Mg}-0.3537$. Vertical bars: standard error. $* * *$, **, *: Significant at 1; 5 and $10 \%$ respectively by Student's t-test

(a)
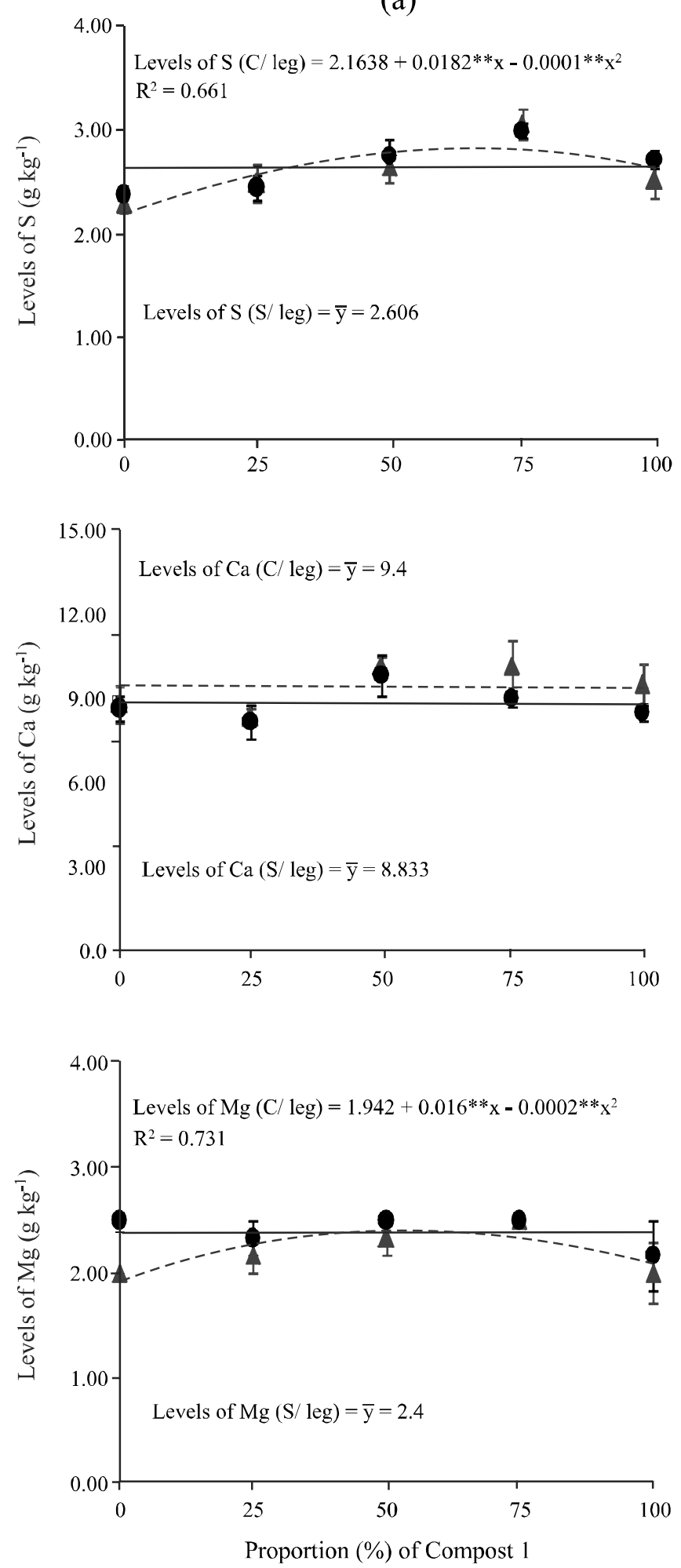

$\triangle$ With legumes (b)

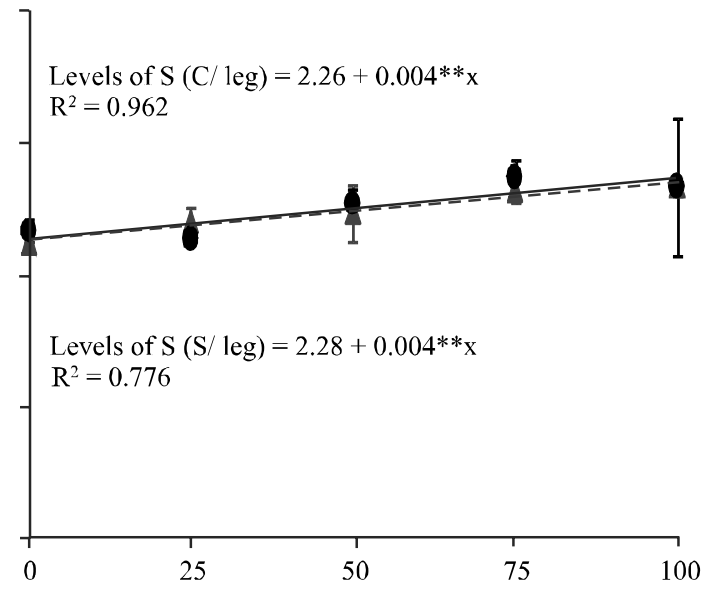

Levels of $\mathrm{Ca}(\mathrm{C} / \mathrm{leg})=8.8+0.016 \mathrm{x}$ $\mathrm{R}^{2}=0.832$

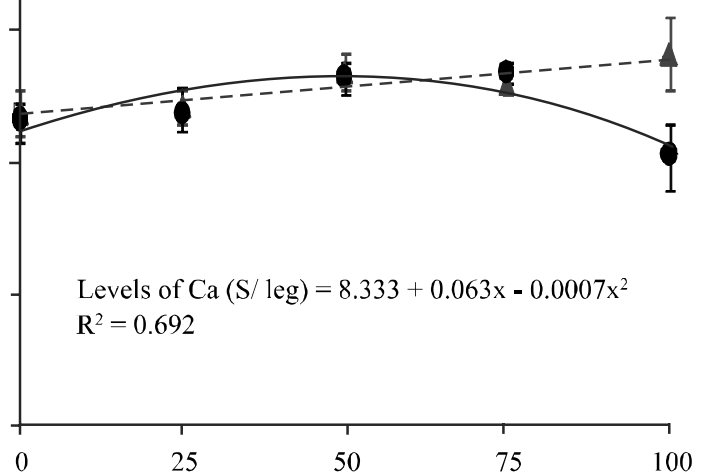

Levels of $\mathrm{Mg}(\mathrm{C} / \mathrm{leg})=2.066+0.004 * x_{\mathrm{x}}$ $\mathrm{R}^{2}=0.692$

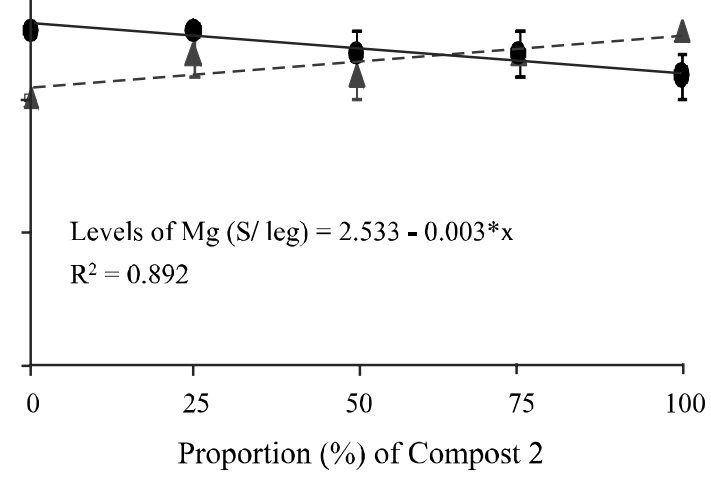

Without legumes 
a probable increase in the availability of $\mathrm{SO}_{4}{ }^{2-}$ through desorption of the minerals in the clay and/or favouring mineralisation, as observed by Nogueira and Melo (2003). Silva et al. (1999) found higher concentrations of $\mathrm{SO}_{4}^{2-}$ due to liming of the soils, a Low Humic Gley and a Red-Yellow Latosoll, which may mean a greater availability of $\mathrm{S}$ for the plants.

In spite of the effects observed for $\mathrm{Ca}$ and $\mathrm{Mg}$ in response to the proportions of the composts used (Figure 3), leaf content for these elements were below those recommended by Partelli et al. (2006a) and Bragança, Prezotti and Lani (2007). After N, Ca is the nutrient most accumulated by the conilon coffee plant (BRAGANÇA;PREZOTTI; LANI, 2007), being essential for cell wall stability and the processes which control the permeability of the plasma membrane (TAIZ; ZEIGER, 2004). Mg is the fourth most-accumulated macronutrient by the conilon (BRAGANÇA; PREZOTTI; LANI, 2007) and, due to its occupying the centre of the chlorophyll molecule, plays a fundamental role in photosynthesis (TAIZ; ZEIGER, 2004).

\section{CONCLUSIONS}

1. The greatest input of organic compost provides higher foliar $\mathrm{P}$ content, due to the reduction in $\mathrm{P}$ adsorption and the improvement in the physical and biological properties of the soil;

2. The increase in the amount of compost enhances foliar $\mathrm{S}$ levels in response to the increase in soil $\mathrm{pH}$;

3. Under conditions similar to this study, for yields of around 61 to 66 bags ha $^{-1}$, the proportion recommended for replacement of the mineral source by the organic is 37 to $40 \%$;

4. Organic fertilization of the coffee plant based on the recommendation of mineral $\mathrm{N}$ to achieve a given output should be reviewed, since with a lesser input of $\mathrm{N}$, higher yields are obtained, which emphasises the role of organic matter as a promoter of plant growth, besides promoting improvements in the chemical, physical and biological properties of the soil;

5. The use of composts from organic waste is an alternative to partly replace mineral fertilizer in the conilon coffee plant, with increases in productivity.

\section{ACKNOWLEDGEMENTS}

The authors wish to acknowledge the support of the Fundação de Amparo à Pesquisa do Espírito Santo
- FAPES, in granting a post-graduate scholarship to the first author. Also the SAF/MDA, SECIS/MCT, by means of $\mathrm{CNPq}$, for their financial support, and the Instituto Capixaba de Pesquisa, Assistência Técnica e Extensão Rural - INCAPER for their logistical support. The authors also wish to thank the farmer and his family for their support, participation and exchange of experiences.

\section{REFERENCES}

ANDRADE, F. V. et al. Adição de ácidos orgânicos e húmicos em Latossolos e adsorção de fosfato. Revista Brasileira de Ciência do Solo, v. 27, n. 6, p. 1003-1011, 2003.

ARAÚJO, J. B. S. et al. Composto orgânico e biofertilizante na nutrição do cafeeiro em formação no sistema orgânico: teores foliares. Coffee Science, v. 2, n. 1, p. 20-28, 2007.

ARAÚJO, J. B. S. et al. Composto orgânico e biofertilizante supermagro na formação de cafeeiros. Coffee Science, v. 3, n. 2, p. 115-123, 2008.

BRAGANÇA, S. M.; PREZOTTI, L. C.; LANI, J. A. Nutrição do cafeeiro conilon. In: FERRÃO, R. G. et al.(Ed.). Café conilon. Vitória, ES: INCAPER, 2007. cap. 11, p. 296-327.

EMPRESA BRASILEIRA DE PESQUISA AGROPECUÁRIA. Sistema brasileiro de classificação de solos. 2. ed. Rio de Janeiro: EMBRAPA Solos, 2006. 306 p.

EMPRESA BRASILEIRA DE PESQUISA AGROPECUÁRIA. Manual de métodos de análises de solo. 2. ed. Rio de Janeiro: Ministério da Agricultura e do Abastecimento, 1997. 212 p.

FERRÃO, R. G. et al. Cultivares de café conilon. In: FERRÃO, R. G. et al. (Ed.). Café conilon. Vitória, ES: INCAPER, 2007. cap. 7, p. 205-225.

GUARÇONI M., A.; MENDONÇA, E. S. Capacidade tampão de $\mathrm{pH}$ do solo e disponibilidade de fósforo pela adição de composto orgânico. Magistra, v. 15, n. 2, 2003.

MALAVOLTA, E.; VITTI, G.C.; OLIVEIRA, S.A. Avaliação do estado nutricional das plantas - princípios e aplicações. Piracicaba, Potafos, 1989. 201 p.

MELO, L. C. A.; SILVA, C. A.; DIAS, B. O. Caracterização da matriz orgânica de resíduos de origens diversificadas. Revista Brasileira de Ciência do Solo, v. 32, n. 1, p. 101-110, 2008.

NARDI, S. et al. Physiological effects of humic substances on higher plants. Soil Biology \& Biochemistry, v. 34, n. 11, p. 1527-1536, 2002.

NOGUEIRA, M. A.; MELO, W. J. Enxofre disponível para a soja e atividade de arilsulfatase em solo tratado com gesso agrícola. Revista Brasileira de Ciência do Solo, v. 27, n. 4, p. $655-663,2003$.

PARTELLI, F. L. et al. Estabelecimento de normas Dris em cafeeiro conilon orgânico ou convencional no estado do Espírito Santo. Revista Brasileira de Ciência do Solo, v. 30, n. 3, p. 443-451, 2006a. 
PARTELLI, F. L. et al. Produção e desenvolvimento radicular de plantas de café 'Conilon' propagadas por sementes e por estacas. Pesquisa Agropecuária Brasileira, v. 41, n. 6, p. 949-954, 2006b.

PREZOTTI, L. C. et al. Calagem e adubação. In: FERRÃO, R. G. et al., (Ed.). Café conilon. Vitória, ES: INCAPER, 2007. cap. 12, p. 341-342.

RANGEL, O. J. P. et al. Carbono orgânico e nitrogênio total do solo e suas relações com os espaçamentos de plantio de cafeeiro. Revista Brasileira de Ciência do Solo, v. 32, n. 5, p. 2051-2059, 2008.

RHEINHEIMER, D. S.; ANGHINONI, I; CONTE, E. Sorção de fósforo em função do teor inicial e de sistemas de manejo de solos. Revista Brasileira de Ciência do Solo, v. 27, n. 1, p. 41-49, 2003.

RICCI, M. S. F. et al. Growth rate and nutritional status of an organic coffee cropping system. Scientia Agricola, v. 62, n. 2, p. 138-144, 2005.
SERRANO, L. A. L.; SILVA, V. M.; FORMENTINI, E. A. Uso de compostos orgânicos no plantio do cafeeiro conilon. Revista Ceres, v. 58, n. 1, p. 100-107, 2011.

SILVA, C. A. et al. Mineralização de nitrogênio e enxofre em solos brasileiros sob influência da calagem e fósforo. Pesquisa Agropecuária Brasileira, v. 34, n. 9, p.1679-1689, 1999.

TAIZ, L.; ZEIGER, E. Fisiologia vegetal. 3. ed. Porto Alegre: Artmed, 2004. 719 p.

THEODORO, V. C. A. et al. Alterações químicas em solo submetido a diferentes formas de manejo do cafeeiro. Revista Brasileira de Ciência do Solo, v. 27, n. 6, p. 1039-1047, 2003.

THEODORO, V. C. A.; MENDES, A. N. G.; GUIMARÃES, R. J. Resposta de lavouras cafeeiras em transição agroecológica a diferentes manejos de solo. Coffee Science, v. 4 , n. 1, p. 56-66, 2009. 